\title{
The mindfulness aspects in the teaching of culinary art in vocational high school
}

\author{
Nur Faizal Adkha *, Putu Sudira iD, Ranu Iskandar \\ Universitas Negeri Yogyakarta. \\ * Corresponding Author. Email: nurfaizaladkha999@gmail.com
}

\section{ARTICLE INFO}

\section{Article History}

Received:

30 January 2021;

Revised:

27 April 2021;

Accepted:

27 June 2021;

Available online:

6 November 2021

\section{Keywords}

Culinary art subjects;

Mindfulness learning;

Vocational high school

\begin{abstract}
This study aims to describe the aspects of mindfulness in the teaching of culinary art in vocational high schools. The aspects of mindfulness in the field of teaching consist of novelty, variety, joyfulness, meaningfulness, and alertness in learning. The benefits of mindfulness are related to the competencies in creativity, communication, collaboration, and critical thinking. These competencies are often referred to as the "Four C's" and are considered important competencies in the 21 st century. The research variables based on theoretical studies in the fields of education and psychology consist of novelty, variety, joyfulness, meaningfulness, and alertness in learning. The population in this study is productive teachers of the department of culinary art at five vocational high schools in the Special Region of Yogyakarta. The specified sample is 30 teachers. The data were collected using a questionnaire. The validity was measured through product-moment testing, and the reliability was measured using the Cronbach alpha model with the SPSS 16.00 program. The data analysis was done using descriptive analysis. The data were analyzed by calculating the ideal score, mean, and standard deviation and by categorizing the data. The results show that the mindfulness aspect of culinary teaching consists of 1.) Novelty, which is in the good category, with a percentage of $53.33 \%$; 2.) Variation, which is in the good category, with a percentage of $66.67 \% ; 3$.) Excitement, which is in the very good category, with a percentage of $60 \%$; 4.) Meaningfulness, which is in the very good category, with a percentage of $76.67 \%$; and 5.) Alertness, which is in the very good category, with a percentage of $70 \%$.
\end{abstract}

This is an open access article under the CC-BY-SA license.

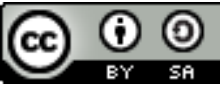

\section{How to cite:}

Adkha, N. F., Sudira, P., \& Iskandar, R. (2021). The mindfulness aspects in the teaching of culinary art in vocational high school. Jurnal Pendidikan Vokasi, 11(2), 155-170.

https://doi.org/10.21831/jpv.v11i2.38402

\section{INTRODUCTION}

In the Industrial Revolution 4, technological advances have changed many things in life, including work competence (Schwab, 2015). The National Employer Skills Survey shows that there are $16 \%$ of job vacancies that are difficult to fill by job seekers because they do not have the right skills for these vacancies. The UKCES survey results show that about $50 \%$ of the workers have the perception that the education system does not teach students sufficient job skills (UK Commission for Employment and Skills, 2010). The data obtained from the Central Bureau of Statistics show that Vocational High School (VHS) graduates are the largest contributors to unemployment data in the Special Region of Yogyakarta (Evani, 2019).

According to the General Manager of Astra Honda Motor, Ahmad Muhibuddin, there is a gap between the capabilities of VHS graduates and the capabilities needed by industry, especially in 
the field of new technology. Bukalapak CEO, Achmad Zaki, stated that the competencies of vocational high school graduates were not in accordance with the competencies needed by the industry (Taufik \& Mulyani, 2018). This problem should be a serious consideration for vocational high school stakeholders and related parties. Other research shows that there are some competencies that are considered quite important in the 21 st century, referred to as the "Four C's". These abilities are in the form of creativity, collaboration, communication, and critical thinking (Davenport \& Pagnini, 2016). An IBM poll involving 1,500 CEOs shows that creativity can shape future leadership skills (Dyer et al., 2011). Vocational high schools should provide their graduates with this ability in order to make it easier for them to work in the industrial sector.

The aspects of mindfulness can be seen as an alternative approach to developing important skills in the 21st century. Creswell (2017) conducted research on mindfulness interventions. The results of his research show that there is an increase in problem-solving performance, feelings of affection, and close relationships with others. In the research, the Kudesia (2015) hypothesis showed a relationship between mindfulness and creativity in its empirical study, and its findings indicate the development in the 'unseen' problem solving. For direct research on the aspects of mindfulness in education, see the Langerian School Report. This report shows that mindfulness can enhance students' "Four C's" competencies and can be a powerful tool or method for undergraduate and secondary schools (Davenport \& Pagnini, 2016). These findings indicate that mindfulness can develop the competencies related to employability, and it is in accordance with the needs of vocational high schools.

Maynard et al. (2017) reports that the number of students who experience emotional disturbances in developing competence to learn at school begins to increase. This issue makes policymakers seek solutions to the social and emotional functioning of students. From these studies, mindfulness has been proven to be effective on health, social, and psychological aspects (Maynard et al., 2017). Another experiment tried to apply mindfulness meditation to teachers. The experiment used an intervention method for teachers and showed that teachers tended to have control over themselves without the need for outside help, which is beneficial to their psychological well-being (Maharani, 2016). Another study found that mindfulness had a significant impact on self-acceptance in young people whose parents were divorced. Surprisingly, the results show that mindfulness significantly affects their self-acceptance as young people whose parents are divorced (Fauzia \& Listiyandini, 2018).

Technological advances in the Industrial Revolution 4.0 era have made humans connect quickly to many people. The previous discussion shows that communication and collaboration are important skills in the 21 st century. This aligns with the basis of the mindfulness theory developed by several experts who emphasize the close relationship with everyone. The developed Rechtschaffen theory comes from Kabar-Zinn's (2001) theory, where mindfulness in the education system must emphasize the student's affection for others, both for other students and for the teacher. The practice of loving-kindness meditation on students is a good treatment for the educational process (Rechtschaffen, 2014). At the Langerian School, the socio-emotional function of both students and teachers increases regardless of social and economic status (Davenport \& Pagnini, 2016). In Langer's (2016) study, students were encouraged to think about possible plans to play together when a new student was in their class. They were encouraged to think about the strengths and weaknesses of the new student so that they could play together (Langer, 2016). Creswell's (2017) research also shows that the compassionate element (loving-kindness meditation) in mindfulness meditation can increase feelings of closeness to others.

Formally and institutionally, the mindfulness approach has not been applied to education in Indonesia, especially in vocational education. Recent research shows that the application of mindfulness to education in Asia is only 5\%, in North America 74\%, Europe 16\%, Canada 5\% (Khng, 2018). This makes it difficult for researchers to conduct experimental research or classroom action research because vocational education has not yet applied the mindfulness approach to the teaching process. Therefore, this research is intended as a preliminary study on the aspects that exist in teaching and relating to mindfulness in learning in vocational high schools.

This study aims to describe the mindfulness aspect of teaching culinary arts in vocational high schools. Mindfulness in learning consists of novelty, variety, joyfulness, meaningfulness, and 
alertness in learning. These aspects or variables come from the theory of sideways learning (Langer, 2016), the seven qualities of mindfulness (Kabat-Zinn, 2013), and the theory of meaningful learning from Ausubel (Sutarto, 2017).

There are various definitions of mindfulness given by experts. Among others is mindfulness as a condition or state (mental or mind), mindfulness as a process, and mindfulness as a practice. In Langer's definition, mindfulness emphasizes the state of awareness that is aware of the context and content of information (Deringer, 2016). Another definition of mindfulness emphasizes a nonjudgmental, continuous, and alert to the present life (Lebuda et al., 2016). The definition of mindfulness as a practice comes from Kabat-Zinn (2013), who states mindfulness as an ancient Buddhist practice of mindfulness that emphasizes living the spirit of life within us and the universe. KabatZinn (2013) emphasizes self-introspection and the ability to appreciate the situatio. The definition of mindfulness as a process emphasizes the process of being openly aware of life experiences. Creswell (2017) says that we often let our minds wander, react automatically (lack of awareness), and be in situations we do not want but try to suppress them. For a deeper understanding of the qualities or principles of mindfulness, the discussion is reviewed by several experts. In Kabat-Zinn's (2013) study, seven attitudes need to be instilled to develop a mindful state. In simple terms, these attitudes need to be applied every day and can be beneficial to mental conditions. Mindfulness's seven attitudes/qualities are non-judgment, patience, beginner thinking, acceptance, moderation, confidence, and resignation.

A non-judgmental attitude is a mental state that frees our minds from judgmental behavior. Human instincts will determine something that has the potential to be a "threat" or "value," but humans are often automatically driven by the thoughts to judge everything. In mindfulness practice, we always cultivate an attitude of not judging everything, including judging others. Patience is an attitude that we must cultivate within ourselves. Mindfulness practice must always place an attitude to patience in everything because sometimes our mind wanders and is turbulent. Accepting our wandering thoughts while controlling ourselves not to worry or rush is a good idea. The beginner's mind is an attitude that always reminds our mind that every day is a new experience to learn. Sometimes in mindfulness practice, we have expectations from the experiences we have had. The beginner's mind cultivates attitudes to see things like the first time. Acceptance is an attitude with which we accept the condition when we are sick and bored and when many things are going on in our mind and body. This concept has revolved around the circle of psychology. Non-striving is an attitude with which we do not push ourselves too big. Many people have goals, including people who learn mindfulness meditation. But those goals can lead them to a stress clinic. In other words, they do not have any expectations. (6) Confidence is an attitude of believing in yourself. This attitude is related to acceptance. It is believing in ourselves and believing in the journey of our lives. Resignation is a mental attitude in which we let go of our feelings, memories, and experiences. Sometimes some memories have strong feelings. Mindfulness trains us to let go of our feelings, memories, and experiences (Kabat-Zinn, 2013).

In his article, Langer (2000) states that several things can make teaching mindful or mindless. To confirm this statement and as a preliminary study, the researcher conducted interviews with teachers and made observations in the culinary expertise program at State Vocational High School 6 Yogyakarta. From the interviews and observations, it can be seen that teachers begin to have a mindset not to judge or label their students. Teachers are more likely to use the methods of hands-on research and discovery learning in their teaching. They support students to be alert, especially during practical learning. They are more likely to use discussion in teaching and support students to make their own hypotheses. They have a mindset that learning should be fun and even students should not be depressed in learning. They always appreciate every teaching process. They support and motivate students to learn from their mistakes. This mindset and attitude can support students to be more mindful.

Several mindsets can lead students into a mindless state like the following. Teachers still think that remembering is very important in education, especially when remembering recipes, and students are required to follow standard operating procedures from recipes. In Langer's (2000) study, 
the mindset of remembering (remembering recipes) and following standard steps (standard operating procedures) can lead students into a mindless state. Even so, it is still a debate among experts about students being required to remember and follow standard operating procedures. For this, the researcher did not conclude and left for further research.

In this discussion, several theories related to mindfulness in education are examined. In Langer's theory, mindfulness is a flexible state of mind, which actively engages in the present moment, pays attention to new things, and is sensitive to different contexts (Langer, 2000). While in the study of his new theory, Langer formed a learning concept called sideways learning. Sideways learning is in the form of: 1.) Openness to novelty; 2.) Awareness of differences; 3.) Sensitivity to different contexts; 4.) Awareness of different perspectives; and 5.) Orientation to the present moment (Langer, 2016).

The first variable of this research is a novelty in learning. This variable is examined from Langer's (2016) theory of openness to novelty and Kabat-Zinn's (2013) theory of the beginner's mind, where every day is a new experience to learn. Novelty in teaching is in the form of measuring the level of teacher intensity in terms of encouraging aspects of novelty in teaching carried out on teaching materials, teaching methods, teaching media, and learning resources. Novelty in teaching materials is in the form of the materials on new technologies in culinary, new cuisines in culinary, new techniques in culinary, new types of work in culinary, and new industries/businesses in culinary. Novelty in teaching methods is about the teachers' use of new methods in teaching. Novelty in teaching media deals with the use of new teaching media (IT, visual media, audio media, etc). Novelty in new learning resources is in the form of the use of the Internet as learning resources and inviting experts to school as learning resources.

The second variable in this study is variation in teaching. This variable is examined from Langer's (2016) theory of awareness of differences, sensitivity to differences in context, and awareness of different perspectives. The basis of this variable comes from Langer's theory and colleagues' research. This study emphasizes the use of more varied instructions compared to fair instructions. For example, in a two-group piano lesson, the first group was asked to memorize and repeat the game, while the second group was asked to vary their piano playing. The provision of varied and conditional instructions also has an effect on learning.

Variation in teaching is in the form of measuring the level of teacher intensity in terms of encouraging aspects of variation in teaching carried out on teaching materials, teaching methods, teaching media, and sources of teaching materials. Variations in teaching materials can be in the form of teachers varying the perspective of the material based on the point of view of culinary workers, culinary business owners, consumers, the varying subject matter related to different types of cuisine, types of cooking utensils, cooking methods, and cooking ingredients. Variation in teaching methods is in the form of teachers often varying teaching methods, teaching media, sources of teaching materials, as well as varying the teaching objectives.

The third variable in this study is joyfulness in learning. This variable comes from KabatZinn's (2013) theory which emphasizes the appreciation of the present moment, Langer's study of turning work into play, and loving-kindness meditation interventions in education (Rechtschaffen, 2014). In Langer's (2016) study, teachers can change the mindset that learning is fun. In addition, thoughts of love or closeness between fellow students and teachers can be developed by thinking about good things about friends and teachers. This has been tested in Langerian schools (Davenport \& Pagnini, 2016). Joyfulness in learning is in the form of measuring the level of teacher intensity to encourage aspects of variety in teaching carried out in the teaching process and methods. The joyfulness in the teaching process can be in the form of a teacher's mindset of learning as a fun activity, and evaluative teacher's attitude, the teacher's attitude in building personal relationships with students (life, interests, and curiosity), and the attitude of teachers who are able to appreciate the abilities of their students. The joyfulness in learning methods can be in the form of teachers often using fun teaching methods and relating the material to students' things.

The fourth variable in this study is meaningfulness in learning. This variable is in the study of Langer's theory, where teaching must encourage students to make their own hypotheses so that they are more meaningful for students (Langer, 2016). It is drawn initially from Kabat-Zinn's (2013) theory of self-confidence. In addition, cognitive teaching theory also emphasizes that learning 
must be meaningful for students, as stated in the meaningful learning theory from Ausubel and handson research \& discovery learning from Bruner (Sutarto, 2017). Meaningful learning theory and discovery learning theory are also emphasized in Langer's (2016) theory of mindfulness learning. Meaningfulness in learning is in the form of measuring the level of teacher intensity to encourage the aspects of meaningfulness in learning carried out on teaching materials, teaching processes, and teaching methods. The meaningfulness of the learning material can be in the form of interpreting the material in the student's personality (life, curiosity, interest) and making the subject matter meaningful for students. Meaningfulness in the learning process can be in the form of teacher attitudes to encouraging students to make their own hypotheses and teacher attitudes to encourage students to learn from failure. Meaningfulness in learning methods can be in the form of teachers often using hands-on research and discovery teaching methods.

The fifth variable in this study is alertness in learning. This variable is derived from Kabat Zinn's theory of inculcating higher alertness, clarity, and self-acceptance (Kabat-Zinn, 2013). Meanwhile, Langer's (2016) developed the concept of soft vigilance, namely alertness that can still respond to the surrounding environment, as previously discussed regarding sideways learning. In the previous variables, the emphasis on novelty and variety in teaching is very important to increase openness to novelty, alertness to differences, sensitivity to context, awareness of different perspectives, and orientation to the current moment in teaching.

Alertness in learning is in the form of measuring the level of teacher intensity in terms of encouraging aspects of alertness in learning carried out on teaching materials, teaching processes, and learning resources. Alertness in learning materials can be in the form of teachers often encouraging students to pay attention and be aware of differences in materials and perspectives (differences in cuisine, cooking utensils, cooking ingredients, cooking work, cooking industry). Alertness to the teaching process can be in the form of teachers being alert to class attendance and teachers encouraging students to learn the theory and practice. Alertness to learning resources can be in the form of teachers encouraging students to pay attention to the differences in each learning resource. Aspects of mindfulness consisting of novelty, variety, joy, meaningfulness, and alertness that are useful for fostering creativity, communication, collaboration, and critical thinking in students can be seen in Figure 1.

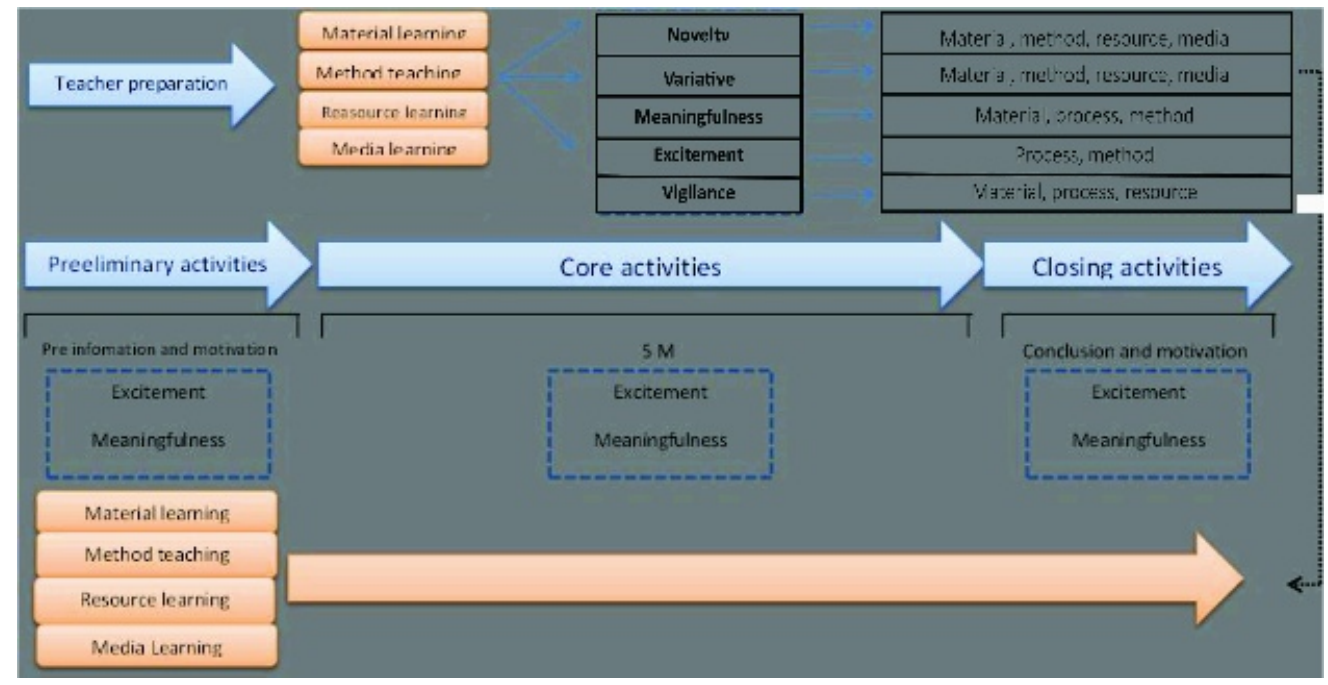

Figure 1. Aspects of Mindfulness

\section{RESEARCH METHOD}

This research is a quantitative descriptive study that describes the variables in the study. The data were processed using descriptive statistical analysis. The categorization of the data used the ideal score. The population in this study is productive Culinary art teachers of vocational high schools in the Special Region of Yogyakarta. The sample is 42 teachers of State Vocational High School 
(SVHS) 6 Yogyakarta, SVHS 4 Yogyakarta, SVHS 2 Godean, and Private Vocational High School 2 Bopkri with the following details, which can be seen in Table 1.

Table 1. Research sample

\begin{tabular}{llc}
\hline No. & Productive Teachers of Culinary art & Total \\
\hline 1. & State Vocational High School 6. Yogyakarta & 15 \\
2. & State Vocational High School 4. Yogyakarta & 15 \\
3. & State Vocational High School 2. Godean & 8 \\
4. & Private Vocational High School 2 Bopkri & 4 \\
\multicolumn{2}{c}{ Total } & 42 \\
\hline
\end{tabular}

According to Sugiyono (2013), the sample is part of the number and characteristics possessed by the population. The number of samples is determined using the Slovin formula which can be seen in Formula 1.

$\mathrm{s}=$ Number of sample

$\mathrm{N}=$ Number of population

$\mathrm{e}=$ Standard error of measurement

$$
\mathrm{s}=\frac{\mathrm{N}}{1+\mathrm{N}(\mathrm{e})^{2}}
$$

From this study, it is known that the number of the population (N) is 42 with the standard error of measurement (e) of $10 \%$, so the number of the sample obtained is as follows:

$$
\begin{gathered}
\text { Number of sample }=\frac{42}{1+42(0.1)^{2}} \\
\text { Number of sample }=\frac{42}{1.42} \\
\text { Number of sample }=29.58 \approx 30
\end{gathered}
$$

This study uses the non-probability sampling method because the data collection was carried out during the outbreak of the Covid-19 virus, so the government made a policy to close schools, including vocational high schools. Therefore, the researcher decided to use the non-probability sampling method by choosing the right respondents to avoid subjectivity in the study.

The data collected in this study used a questionnaire. According to Buchari, a questionnaire is a list of questions given to other people who are willing to respond (respondents) in accordance with user requests (Alma, 1993). The questionnaire is in the form of a closed questionnaire, where the respondent only needs to put a checkmark to answer each question. The following are the steps the researcher took to make the instrument: 1.) Determining the variables based on the theoretical study that has been discussed in the previous section. There are five variables to be studied in this study, namely novelty, variety, excitement, meaningfulness, and alertness in learning; 2.) Dividing the stages in teaching, such as in the frame of mind starting from preliminary activities, core activities, and closing activities; 3.) Dividing teaching components in the form of teaching materials, teaching media, learning resources, teaching methods, teaching processes, teaching outcomes; 4.) Construct an instrument grid based on the variables made and provide indicators for each sub variable according to the stages and components of teaching; and 5.) Making instruments based on the grid that has been made.

The validity test aims to test whether the questionnaire is feasible to be used as a research instrument. A measuring device is said to be valid if it can be used to measure what should be measured (Sugiyono, 2013). Validity shows the degree of accuracy between the data that are actually about an object and the data that the researcher can collect. The validity test used in this study is the product-moment correlation, resulting in four invalid or lower than reliable items, so four items are 
omitted. A reliable instrument is an instrument that can be trusted to be used as a data collection tool; it is not tendentious, or it does not direct respondents to choose certain answers (Arikunto, 2013). The data that had been obtained were analyzed using Cronbach's Alpha formula with the help of the SPSS 16.0 program. The value obtained is 0.956 , which is greater than 0.600 , so that the instrument is declared reliable.

\section{RESULT AND DISCUSSION}

The results regarding the novelty variable come from Items 1-11 of the instrument. Each item consists of five answer choices: never, rarely, sometimes, often, and always with a score of 1 to 5 , respectively. The result of empirical data from the questionnaire that has been filled in by 30 teachers of the department of culinary art is can be seen in Table 2 .

Table 2. Empirical Data of Novelty in Teaching

\begin{tabular}{ll}
\hline Variable & Score \\
\hline R1 & 43 \\
R2 & 53 \\
R3 & 53 \\
R4 & 35 \\
R5 & 45 \\
R6 & 50 \\
R7 & 45 \\
R8 & 27 \\
R9 & 38 \\
R10 & 33 \\
R11 & 35 \\
R12 & 41 \\
R13 & 43 \\
R14 & 43 \\
R15 & 49 \\
R16 & 31 \\
R17 & 31 \\
R18 & 38 \\
R19 & 36 \\
R20 & 39 \\
R21 & 42 \\
R22 & 34 \\
R23 & 38 \\
R24 & 42 \\
R25 & 35 \\
R26 $27 ~$ & 34 \\
R28 & 41 \\
R29 & 40 \\
R30 & 41 \\
\hline
\end{tabular}

The data on novelty in learning culinary art was analyzed by calculating the range of ideal scores. The ideal score range was calculated from the number of questions multiplied by the maximum score. The novelty variable in teaching has 11 questions with a maximum score of five, so that the ideal score range is 55. Meanwhile, to get the ideal average, the ideal score range was divided by two, and the resulting number was 27.5 . The standard deviation was obtained from the ideal mean divided by three. The result of the analysis is presented in Table 3 . 
Table 3. Analysis of Novelty in Teaching

\begin{tabular}{ll}
\hline Analysis & Score \\
\hline Ideal Score Range & 55 \\
pi mean (MD) & 27.5 \\
Standard deviation & 9.16667 \\
Minimum value & 11 \\
\hline
\end{tabular}

To categorize the data, the researcher divided them into five classes, namely very good, good, fair, poor, and very poor. Class determination was established based on the ideal score range, ideal mean, standard deviation, and minimum score so that the data could be distributed properly. Furthermore, the frequency was calculated from the data that had been obtained, and the percentage was determined from that frequency. The result of the categorization of novelty in teaching is shown in Table 4.

Table 4. Categorization of Novelty in Teaching

\begin{tabular}{llll}
\hline Category & Score Range & Frequency & Percentage \\
\hline Very good & $41.25<\mathrm{x} \leq 55$ & 11 & $36.67 \%$ \\
Good & $32.08333<\mathrm{x} \leq 41.25$ & 16 & $53.33 \%$ \\
Fair & $22.916667<\mathrm{x} \leq 32.08333$ & 3 & $10 \%$ \\
Poor & $13.75<\mathrm{x} \leq 22.916667$ & 0 & $0 \%$ \\
Very poor & $11<\mathrm{x} \leq 13.75$ & 0 & $0 \%$ \\
\hline
\end{tabular}

The result of the data analysis shows that novelty in teaching has the largest frequency in the good category, with a percentage of $53.33 \%$. The second-largest frequency is in the very good category, with a percentage of 36.67 , and the third largest frequency is in the normal category with a percentage of $10 \%$. The other category has a frequency of 0 . From the results of the analysis above, it can be stated that the novelty in teaching in the field of culinary art is in a good category.

Novelty in teaching is explained in mindfulness theory, openness to innovation or new science and technology (Langer, 2016), and thinking like a beginner (Kabat-Zinn, 2013). Novelty in teaching emphasizes the teacher's efforts to bring new experiences and/or information into the teaching process. Delivering novelty in teaching can be done through teaching materials, teaching methods, teaching media, and learning resources. Novelty in teaching in the field of culinary art can be linked to novelties in the culinary industry, including the latest technology, the latest cooking utensils, the latest cooking methods, new jobs in the culinary industry, and so on. Delivering novelty in teaching can create the mental condition of students to think like a beginner.

The result of the variable of variation in teaching is from Items 12-26 of the instrument. Each item consists of five answer choices: never, rarely, sometimes, often, and always with a score of 1 to 5 , respectively. The results of empirical data from a questionnaire that has been filled out by 30 teachers majoring in culinary arts can be seen in Table 6.

The data on the variation in the teaching of culinary art was analyzed by calculating the range of ideal scores. The ideal score range was calculated from the number of questions multiplied by the maximum score. The variation variable in teaching had 15 items with a maximum score of five, so that the ideal score range was 75 . Meanwhile, to get the ideal average was by dividing the ideal score range by two, resulting in 37.5. The standard deviation was obtained from the ideal mean divided by three. The result of the analysis is presented in Table 5 .

Table 5. Analysis of Variation in Teaching

\begin{tabular}{ll}
\hline Analysis & Score \\
\hline Ideal Score Range (SD) & 75 \\
Ideal mean(MD) & 37.5 \\
Standard deviation & 12.5 \\
Minimum score & 15 \\
\hline
\end{tabular}


Table 6. Empirical Data on Variation in Teaching

\begin{tabular}{ll}
\hline Variable & Score \\
\hline R1 & 58 \\
R2 & 67 \\
R3 & 67 \\
R4 & 52 \\
R5 & 56 \\
R6 & 61 \\
R7 & 56 \\
R8 & 50 \\
R9 & 44 \\
R10 & 51 \\
R11 & 45 \\
R12 & 46 \\
R13 & 55 \\
R14 & 55 \\
R15 & 65 \\
R16 & 52 \\
R17 & 52 \\
R18 & 58 \\
R19 & 55 \\
R20 & 51 \\
R21 & 60 \\
R22 & 48 \\
R23 & 45 \\
R24 & 56 \\
R25 & 58 \\
R26 & 54 \\
R27 & 49 \\
R28 & 59 \\
R29 & 59 \\
R30 & 48 \\
\hline &
\end{tabular}

To categorize the data, the researcher divided them into five classes, namely very good, good, fair, poor, and very poor. Class determination was established based on the ideal score range, ideal mean, standard deviation, and minimum score so that the data could be distributed properly. Furthermore, the frequency was calculated from the data that had been obtained, and the percentage was determined from the frequency. The result of the categorization of variation in teaching is presented in Table 7.

Table 7. Categorization of Variation in Teaching

\begin{tabular}{llll}
\hline Category & Score Range & Frequency & Percentage \\
\hline Very good & $56.25<\mathrm{x} \leq 75$ & 10 & $33.33 \%$ \\
Good & $43.75<\mathrm{x} \leq 56.25$ & 20 & $66.67 \%$ \\
Fair & $31.25<\mathrm{x} \leq 43.75$ & 0 & $0 \%$ \\
Poor & $18.75<\mathrm{x} \leq 31.25$ & 0 & $0 \%$ \\
Very poor & $15<\mathrm{x} \leq 18.75$ & 0 & $0 \%$ \\
\hline
\end{tabular}

The result of the data analysis shows that the variation in teaching has the largest frequency in either category with a percentage of $66.67 \%$. The second frequency is very good with a percentage of $33.33 \%$. The other category has a frequency of 0 . From the data analysis, it can be stated that the variation in teaching in the field of culinary art is in a good category. 
Variation in teaching has been explained in the mindfulness theory, where it is emphasized to use things that are varied rather than standard (Langer, 2016). Variation in teaching emphasizes the teacher's efforts to bring varied experiences and/or information to students so that students become more alert and sensitive to different perspectives and contexts. Teachers can do variations in teaching through teaching materials, teaching methods, teaching media, and learning resources.

The result of the joyfulness variable in teaching is from Items 26-34 of the instrument. Each item consists of five answer choices: never, rarely, sometimes, often, and always with a score of 1 to 5 , respectively. The result of empirical data from the questionnaire that has been filled out by 30 teachers of the department of culinary arts can be seen in Table 8 .

Table 8. Empirical Data on Joyfulness in Learning

\begin{tabular}{ll}
\hline Variable & Score \\
\hline R1 & 25 \\
R2 & 29 \\
R3 & 29 \\
R4 & 26 \\
R5 & 28 \\
R6 & 29 \\
R7 & 28 \\
R8 & 28 \\
R9 & 27 \\
R10 & 26 \\
R11 & 25 \\
R12 & 21 \\
R13 & 32 \\
R14 & 32 \\
R15 & 32 \\
R16 & 26 \\
R17 & 26 \\
R18 & 28 \\
R19 & 26 \\
R20 & 27 \\
R21 & 27 \\
R22 & 22 \\
R23 & 26 \\
R24 & 32 \\
R26 & 28 \\
R27 & 27 \\
R28 & 23 \\
R30 & 28 \\
& 28 \\
\hline
\end{tabular}

The data on joyfulness in learning culinary art was analyzed by calculating the ideal score range. The ideal score range was calculated from the number of questions multiplied by the maximum score. The joyfulness variable in teaching had seven questions with a maximum score of five, so that the ideal score range is 35 . Meanwhile, to get the ideal mean was by dividing the ideal score range by two, and the result was 17.5. The standard deviation was obtained from the ideal mean divided by three. The result of the analysis is presented in Table 9 .

To categorize the data, the researcher divided them into five classes, namely very good, good, fair, poor, and very poor. Class determination was established based on the ideal score range, ideal mean, standard deviation, and minimum score so that the data could be distributed properly. Furthermore, the frequency was calculated from the data that had been obtained, and the percentage 
was determined from the frequency. The result of the categorization of joyfulness in learning is presented in Table 10.

Table 9. Analysis of Joyfulness in Learning

\begin{tabular}{ll}
\hline Analysis & Score \\
\hline Ideal Score Range (SD) & 35 \\
Ideal mean (MD) & 17.5 \\
Standard deviation & 5.8333 \\
Minimum score & 7 \\
\hline
\end{tabular}

Table 10. Categorization of Joyfulness in learning

\begin{tabular}{llll}
\hline Category & Score Range & Frequency & Percentage \\
\hline Very good & $26.25<\mathrm{x} \leq 35$ & 18 & $60 \%$ \\
Good & $20.41667<\mathrm{x} \leq 26.25$ & 12 & $40 \%$ \\
Fair & $14.5833<\mathrm{x} \leq 20.41667$ & 0 & $0 \%$ \\
Poor & $8.75<\mathrm{x} \leq 14.5833$ & 0 & $0 \%$ \\
Very poor & $7<\mathrm{x} \leq 8.75$ & 0 & $0 \%$ \\
\hline
\end{tabular}

Table 11. Empirical Data of Meaningfulness in Learning

\begin{tabular}{cc}
\hline Variable & Score \\
\hline R1 & 21 \\
R2 & 23 \\
R3 & 23 \\
R4 & 19 \\
R5 & 20 \\
R6 & 19 \\
R7 & 20 \\
R8 & 20 \\
R9 & 19 \\
R10 & 21 \\
R11 & 18 \\
R12 & 15 \\
R13 & 23 \\
R14 & 23 \\
R15 & 25 \\
R16 & 20 \\
R17 & 20 \\
R18 & 20 \\
R19 & 17 \\
R20 & 21 \\
R21 & 20 \\
R22 & 16 \\
R23 & 17 \\
R24 & 23 \\
R25 & 20 \\
R26 & 20 \\
R27 & 18 \\
R28 & 20 \\
R30 & 20 \\
&
\end{tabular}


The result of the data analysis shows that joyfulness in learning has the largest frequency in the very good category with a percentage of $60 \%$. The second-largest frequency in the category is good with a percentage of $40 \%$. The other category has a frequency of 0 . From the analysis of the data above, it can be stated that the joyfulness in learning in the culinary field is in a very good category. The joyfulness of teaching is an important part of the mindfulness learning theory. In the field of education, some mindsets, such as delaying excitement to achieve a goal in teaching, can lead students to a mindless condition, more specifically, can make the mind wander. In the mindfulness theory, it is necessary to have a mindset that working/learning is fun (Langer, 2016), and/or can be done by having an attitude to appreciating every existing condition (Kabat-Zinn, 2013). Joyfulness in learning can be done through teaching methods, teaching processes, and teaching media. The teacher must know the student's personal condition (interests, curiosity, life) in this case.

The results of the analysis of meaningfulness in learning are from Items 35-39 of the instrument. Each item consists of five answer choices: never, rarely, sometimes, often, and always with a score of 1 to 5, respectively. The result of the analysis of the empirical data from the questionnaire that had been filled in by 30 teachers of the department of culinary art can be seen in Table 11.

The data on meaningfulness in learning culinary art was analyzed by calculating the ideal score range. The ideal score range was calculated from the number of questions multiplied by the maximum score. The meaningfulness variable in teaching had five questions with a maximum score of five, so that the ideal score range was 25 . Meanwhile, to get the ideal mean was by dividing the ideal score range by two, and the result was 12.5 . The standard deviation was obtained from the ideal mean divided by three. The result of the analysis is presented in Table 12 .

Table 12. Analysis of Meaningfulness in Learning

\begin{tabular}{ll}
\hline Analysis & Score \\
\hline Ideal Score Range (SD) & 25 \\
Ideal mean(MD) & 12.5 \\
Standard deviation & 4.1667 \\
Minimum score & 5 \\
\hline
\end{tabular}

To categorize the data, the researcher divided them into five classes, namely very good, good, fair, poor, and very poor. Class determination was established based on the ideal score range, ideal mean, standard deviation, and minimum score so that the data could be distributed properly. Furthermore, the frequency was calculated from the data that had been obtained, and the percentage was determined from the frequency. The result of the categorization of meaningfulness in learning is presented in Table 13.

Table 13. Categorization of Meaningfulness in Learning

\begin{tabular}{llll}
\hline Category & Score Range & Frequency & Percentage \\
\hline Very good & $18.75<\mathrm{x} \leq 25$ & 23 & $76.67 \%$ \\
Good & $14.5833<\mathrm{x} \leq 18.75$ & 7 & $23.33 \%$ \\
Fair & $10.41667<\mathrm{x} \leq 14.5833$ & 0 & $0 \%$ \\
Poor & $6.25<\mathrm{x} \leq 10.41667$ & 0 & $0 \%$ \\
Very poor & $5<\mathrm{x} \leq 6.25$ & 0 & $0 \%$ \\
\hline
\end{tabular}

Based on Table 13, meaningfulness in learning has the largest frequency in the very good category with a percentage of $76.67 \%$. The second-largest frequency is in a good category, with a percentage of $23.33 \%$. The other category has a frequency of 0 . From the data analysis, it can be stated that the meaningfulness in learning is very good. 
The teacher can do meaningfulness in learning through teaching materials, teaching processes, and teaching methods. Preparation of teaching materials to be more meaningful for students can be done by linking teaching information with students' personal information. In Ausubel's meaningful learning theory, teaching materials must be assimilated into the student's personality without abridging (Sutarto, 2017), which is in accordance with the principles of the mindfulness learning theory. In addition, Langer (2016) added to use hands-on research and discovery teaching. Furthermore, inculcating an attitude of self-confidence is also one of the qualities of mindfulness (Kabat-Zinn, 2013).

The results of the analysis of alertness in learning are from Items 40-51 of the instrument. Each item consists of five answer choices: never, rarely, sometimes, often, and always with a score of 1 to 5 , respectively. The result of empirical data from the questionnaire that has been filled in by 30 teachers of the department of culinary art can be seen in Table 14 .

Table 14. Empirical Data on Mindfulness in Learning

\begin{tabular}{cc}
\hline Variable & Score \\
\hline R1 & 47 \\
R2 & 48 \\
R3 & 48 \\
R4 & 49 \\
R5 & 48 \\
R6 & 48 \\
R7 & 48 \\
R8 & 45 \\
R9 & 46 \\
R10 & 47 \\
R11 & 46 \\
R12 & 36 \\
R13 & 51 \\
R14 & 51 \\
R15 & 60 \\
R16 & 44 \\
R17 & 44 \\
R18 & 49 \\
R19 & 41 \\
R20 & 42 \\
R21 & 48 \\
R22 & 37 \\
R23 & 36 \\
R24 & 50 \\
R25 & 47 \\
R26 & 48 \\
R27 & 47 \\
R28 & 48 \\
R30 & 48 \\
& 37 \\
\hline
\end{tabular}

The data on alertness in the learning of culinary lessons were analyzed by calculating the ideal score range. The ideal score range was calculated from the number of questions multiplied by the maximum score. The variable of alertness in learning has 12 questions with a maximum score of five, so that the ideal score range is 60 . Meanwhile, to get the ideal mean was by dividing the ideal score range by two, and the result was 30 . The standard deviation was obtained from the results of the calculation of the ideal mean divided by three. The result of the analysis is presented in Table 15. 
Table 15. Analysis of Alertness in Learning

\begin{tabular}{ll}
\hline Analysis & Score \\
\hline Ideal Score Range (SD) & 60 \\
Ideal mean (MD) & 30 \\
Standard deviation & 10 \\
Minimum score & 12 \\
\hline
\end{tabular}

To categorize the data, the researcher divided them into five classes, namely very good, good, fair, poor, and very poor. Class determination was established based on the ideal score range, ideal mean, standard deviation, and minimum score so that the data could be distributed well. Furthermore, the frequency was calculated from the data that had been obtained, and the percentage was determined from the frequency. The result of categorizing mindfulness in learning is presented in Table 16.

Table 16. Categorization of Alertness in Learning

\begin{tabular}{llll}
\hline Category & Score Range & Frequency & Percentage \\
\hline Very good & $45<\mathrm{x} \leq 60$ & 21 & $70 \%$ \\
Good & $35<\mathrm{x} \leq 45$ & 9 & $30 \%$ \\
Fair & $25<\mathrm{x} \leq 35$ & 0 & $0 \%$ \\
Poor & $15<\mathrm{x} \leq 25$ & 0 & $0 \%$ \\
Very poor & $45<\mathrm{x} \leq 60$ & 21 & $70 \%$ \\
\hline
\end{tabular}

Table 15 shows that alertness in learning has the largest frequency in the very good category with a percentage of $70 \%$. The second-largest frequency is in a good category, with a percentage of $30 \%$. Another category has a frequency of 0 . Therefore, alertness in learning can be stated very well. Mindfulness is learning can be linked to being alert to the present moment and non-judgmental. In the mindfulness theory, attention to the present moment and a non-judgmental attitude can increase alertness (Kabat-Zinn, 2013). In the theory of sideways learning, alertness is related to being alert and sensitive to differences in context and perspectives (Langer, 2016). Teachers can do alertness in learning by encouraging students to pay attention to differences in teaching materials such as different perspectives of consumers, culinary industry workers, managers, and owners. The teacher must also be aware of the attention of the class and individual students. Teachers can also encourage students to be aware of both theoretical and practical learning.

Table 17. Categorization of Mindfulness Learning Aspects

\begin{tabular}{llllll}
\hline Aspect & Very good & Good & Fair & Poor & Very poor \\
\hline Novelty in learning & $36.67 \%$ & $53.33 \%$ & $10 \%$ & $0 \%$ & $0 \%$ \\
Variation in learning & $33.33 \%$ & $66.67 \%$ & $0 \%$ & $0 \%$ & $0 \%$ \\
Joyfulnessfulness in learning & $60 \%$ & $40 \%$ & $0 \%$ & $0 \%$ & $0 \%$ \\
Meaningfulness in learning & $76.67 \%$ & $23.33 \%$ & $0 \%$ & $0 \%$ & $0 \%$ \\
Alertness to learning & $70 \%$ & $30 \%$ & $0 \%$ & $0 \%$ & ) $0 \%$ \\
\hline
\end{tabular}

\section{CONCLUSION}

Based on the data that have been analyzed and discussed with 30 respondents of culinary art subject teachers, the following conclusions can be drawn: 1.) The aspect of novelty related to new dishes, new cooking utensils, and new businesses in the culinary field can be given by teachers through teaching preparation, materials, methods, learning resources, and teaching media. This aspect relates to openness to reforming and thinking attitude as a beginner, which is in accordance with the nature of attention in teaching culinary art in vocational high schools. It is in a good category, with a percentage of $53.33 \%$; 2.) Teachers can make the aspects of variation on information in teaching through teaching preparation, materials, methods, learning resources, and teaching media. 
This aspect relates to being alert and sensitive to contextual differences and perspectives that can increase creativity in teaching culinary art in vocational high school. It is in a good category, with a percentage of $66.67 \%$; 3.) Teachers can apply the joyfulness aspect by knowing students' personalities through teaching methods and media. This aspect is able to change the mindset of work into a game and appreciate every moment of teaching in vocational high school. It is in a very good category, with a percentage of $60 \%$; 4.) The teacher can carry out the aspect of meaningfulness through preliminary, core, and closing activities. This aspect relates to the student's personality, which can be applied through meaningful learning and discovery learning so as to increase the students' confidence in learning culinary art in vocational high school. It is in a very good category with a percentage of $76.67 \%$; and 5.) The teacher carries the aspect of alertness in the preliminary, core, and closing activities. This aspect can encourage alertness and sensitivity to different perspectives according to sideways learning when teaching the theory and practice of culinary art in vocational high schools. It is in a very good category, with a percentage of $70 \%$.

Based on the conclusions above, the implications are as follows: 1.) Teaching in the field of culinary expertise is more open to novelty. The students are encouraged to learn about new things in the culinary field; 2.) Teaching in the field of culinary expertise is more varied. The students are encouraged to learn many differences in the culinary field rather than learning about one thing; 3. ) Learning in the field of gastronomy is more fun so that students do not feel burdened when learning gastronomy; 4.) Learning in the field of culinary expertise becomes more meaningful. The students are encouraged to link learning with their lives; and 5.) Learning in the field of culinary expertise is more alert. The students are always encouraged to be aware of differences in material as well as those in learning the theory and practice.

Based on the research, the following suggestions are made: 1.) Teachers can develop teaching activities starting from lesson planning, introduction, core, and closing activities by paying attention to the aspects of novelty, variety, joyfulness, meaningfulness, and alertness in learning; and 2.) The government, education offices, schools, and related stakeholders can assist teachers by creating training programs related to mindfulness learning.

\section{REFERENCES}

Alma, B. (1993). Pengantar bisnis. Alfabeta.

Arikunto, S. (2013). Prosedur penelitian: Suatu pendekatan praktik. Rineka Cipta.

Creswell, J. D. (2017). Mindfulness interventions. Annual Review of Psychology, 68(1), 491-516. https://doi.org/10.1146/annurev-psych-042716-051139

Davenport, C., \& Pagnini, F. (2016). Mindful learning: a case study of Langerian mindfulness in schools. Frontiers in Psychology, 7, 1372. https://doi.org/10.3389/fpsyg.2016.01372

Deringer, S. A. (2016). Mindful place-based education: Incorporating mindfulness as a tool for place-based educators. Washington State University.

Dyer, J., Gragersen, H., \& Christensen, C. M. (2011). The innovator's DNA: Mastering the five skills of disruptive innovators. Harvard Business Review Press.

Evani, F. S. (2019, February 22). Lulusan SMK penyumbang besar pengangguran di DIY. Beritasatu.Com. https://www.beritasatu.com/nasional/539488/lulusan-smk-penyumbangbesar-pengangguran-di-diy

Fauzia, R., \& Listiyandini, R. A. (2018). Peran trait mindfulness (rasa kesadaran) terhadap penerimaan diri pada remaja dengan orangtua bercerai. Seminar Nasional Dan Temu Ilmiah Positive Psikologi 2018, 152-163. https://www.researchgate.net/profile/Ratih-ArruumListiyandini/publication/329041137 Peran Trait Mindfulness Rasa Kesadaran Terhadap Penerimaan_Diri_Pada_Remaja_Dengan_Orangtua_Bercerai/links/5 $\bar{b}$ _ec584a6 $\overline{f d c c} 3 \mathrm{a} 8 \mathrm{de}$ 220a9/Peran-Trait-Mindfulness-Rasa-Kesadaran 
Kabar-Zinn, J. (2001). Mindfulness meditation in everyday life. Piatkus Books. http://realestateconsultingservice.com/wp-content/uploads/2018/03/97291641Mindfulness-Meditation-for-Everyday-Life-Kabat-Zinn-Jon.pdf

Kabat-Zinn, J. (2013). Full catastrophe living, revised edition: How to cope with stress, pain and illness using mindfulness meditation. Piatkus Books.

Khng, K. H. (2018). Mindfulness in education: The case of Singapore. Learning: Research and Practice, 4(1), 52-65. https://doi.org/10.1080/23735082.2018.1428120

Kudesia, R. S. (2015). Mindfulness and creativity in the workplace. In J. Reb \& P. W. B. Atkins (Eds.), Mindfulness in Organizations: Foundations, Research, and Applications (pp. 190212). Cambridge University Press. https://doi.org/10.1017/CBO9781107587793.010

Langer, E. J. (2000). Mindful learning. Current Directions in Psychological Science, 9(6), 220-223. https://doi.org/10.1111/1467-8721.00099

Langer, E. J. (2016). The power of mindful learning. Da Capo Press.

Lebuda, I., Zabelina, D. L., \& Karwowski, M. (2016). Mind full of ideas: A meta-analysis of the mindfulness-creativity link. Personality and Individual Differences, 93, 22-26. https://doi.org/10.1016/j.paid.2015.09.040

Maharani, E. A. (2016). Pengaruh pelatihan berbasis mindfulness terhadap tingkat stres pada guru PAUD. Jurnal Penelitian Ilmu Pendidikan, 9(2), 100-110. https://doi.org/10.21831/jpipfip.v9i2.12919

Maynard, B. R., Solis, M. R., Miller, V. L., \& Brendel, K. E. (2017). Mindfulness-based intervenions for improving cogniion, academic achievement, behavior, and socioemoional funcioning of primary and secondary school students. Campbell Systematic Reviews, 13(1), 1-144. https://doi.org/10.4073/csr.2017.5

Rechtschaffen, D. (2014). The way of mindful education: Cultivating well-being in teachers and students. W. W. Norton \& Company.

Schwab, K. (2015). The fourth industrial revolution: What it means and how to respond. Foreignaffairs.Com. https://www.foreignaffairs.com/articles/2015-12-12/fourth-industrialrevolution

Sugiyono, S. (2013). Metode penelitian pendidikan: Pendekatan kuantitatif, kualitatif, dan $R \& D$ (17th ed.). Alfabeta.

Sutarto, S. (2017). Teori kognitif dan implikasinya dalam pembelajaran. Islamic Counseling : Jurnal Bimbingan Dan Konseling Islam, 1(2), 1-26. https://doi.org/10.29240/jbk.v1i2.331

Taufik, W., \& Mulyani, Y. sri. (2018). Analisis Dampak Penggunaan Media Sosial. 4(Mei), 1-7.

UK Commission for Employment and Skills. (2010). Employability: Incentivising improvement. UKCES. https://www.voced.edu.au/content/ngv:44592 